International Journal of Environment, Agriculture and Biotechnology
Vol-6, Issue-2; Mar-Apr, 2021
JJEAB
Journal Home Page Available: https://ijeab.com/
Journal DOI: $10.22161 /$ ijeab

\title{
Effect of the Marination Time \& Marinade Ingredients on Sensory Evaluation of Tawouk
}

\author{
Rana Dally ${ }^{1, a}$, Ali Alkatib ${ }^{1, a}$, Hassan S. HajjHussein ${ }^{2, b}$, and Sami Tlais ${ }^{2, a, b *}$
}

${ }^{1}$ Nutrition and Food Science Department, Lebanese International University, Beirut ${ }^{\mathrm{a}} / \mathrm{Bekaa}^{\mathrm{a}}$, Lebanon.
${ }^{2}$ Biological and Chemical Department, Lebanese International University, Bekaa $/$ Rayak $^{\mathrm{b}}$, Lebanon.
${ }^{*}$ Correspondence should be addressed to Sami Tlais, Email: sami.tlais@ @liu.edu.lb

Received: 03 Jan 2021; Received in revised form: 21 Feb 2021; Accepted: 21 Mar 2021; Available online: 23 Apr 2021

C2021 The Author(s). Published by Infogain Publication. This is an open access article under the CC BY license

(https://creativecommons.org/licenses/by/4.0/).

\begin{abstract}
Tawouk is the chicken's breast meat. Traditionally, meat has been marinated to improve flavor, improve tenderness, and increase product shelf life. The purpose of the marinating time is to permit the marinade to soak as deeply into the food as potential. Here, we studied the effect of marinating time and marinade ingredients on color, flavor, juiciness, chewiness and overall acceptability of chicken breast meat. Our results showed a difference in color, flavor and juiciness between different treatments according to the panelists. Panelists preferred red-colored chicken meat with a strong flavor. We also showed a correlation between color and the overall acceptability of breast chicken meat. This work is laying the ground for better customer service for poultry businesses and restaurant chains. Our work shows that focusing on color is essential to increase consumers' acceptability.
\end{abstract}

Keywords - Lebanon, Tawouk, marinade, marinating time, sensory evaluation.

\section{INTRODUCTION}

Lebanon is characterized by a high level of meat consumption per capita compared to Mediterranean countries [1]. The increase in poultry demand leads to various poultry products that became one of the most popular traditional dishes in Lebanon, such as Tawouk, which is marinated chicken breast meat [1]. Traditionally, meat has been marinated to improve flavor, improve tenderness, and increase product shelf life [2]. There are three strategies for manufacturing marinated products, which are immersion, injection, and vacuum tumbling [2]. The purpose of the marinating time is to permit the marinade to soak deeply into the meat [3]. Allowing the meat to stay within the marinade for a long time might increase toughness, which is the opposite of what is desired. Marinating times vary depending on the sort, cut, and size of the meat. Thinly cut meat can infuse marinade more than thick cuts and need less marinating duration [4]. A good marinade can have the right balance of flavorings components, organic acids, and oil. Vinegar, tomato sauce, or citrus juice are commonly used acids that soften the meat by denaturing the meat proteins. Oils are used to moisten and flavor the meat. Wide varieties of ingredients are used concerning flavorings, such as fresh or dried herbs and spices [4].

Flavors and spices included in marinades upgrade meat's quality and control or limit lipid oxidation [5]. Oxidation in meat products causes muscle protein and fat changes, negatively affecting the product's consumer acceptability after few days [6].

The standard marinade components are water, salt, and phosphates [7, 8]. The salt and phosphate particles in the cells ensure the water maintenance limit of muscles by separating muscle fibers' protein structure and causing expansion of myofibrils [9]. Salt improves the growth of protein structures; however, it doesn't solubilize the greater part of the fiber proteins, autonomously [10]. Offer and Trinic proposed that the chloride particles stick to the fibers and increase electrostatic powers [11]. This permits the fiber network to grow and shape a bigger hole between the actin and myosin in myofibrils. The salt concentration in marinade influences the chemical gradients, the waterholding capacity, and the mass transfer level. Phosphates eliminate the cross-joints among actin and myosin fibrils 
[11]. Hence, a mix of sodium chloride and phosphates is fundamental to improve poultry meat's general delicacy and succulence. The allowed upper level of phosphates (separately or in the blend) in the worldwide food industry is $0.5 \%$ [12].

The main reason of this study is to examine the effect of marination duration and marinade ingredients on the color, flavor, chewiness, and juiciness of Tawouk.

\section{METHODS}

\subsection{Experimental Design}

The experiment design was a $3 \times 3$ factorial arrangement of treatments evaluating three marination solutions and three holding times. Nine chicken breast meat samples from a local restaurant in Anjar (average weight $\pm \mathrm{SD}$, $1000 \pm 5 \mathrm{~g}$ each) were randomly allocated to three marination solutions: mix one, mix two, and mix three. After marination, the meat samples from each mix were subdivided $(\mathrm{n}=20)$ according to holding times of 3,6 , and $12 \mathrm{~h}$ at $4^{\circ} \mathrm{C}$.

\subsection{Preparation of Marinade}

The three marinade solutions were prepared, as mentioned in Table 1. These quantities were used for every $500 \mathrm{~g}$ of breast meat. These mixes were chosen based on a questionnaire done on 35 producers to find out the most used ingredients by Lebanese people to marinate breast meat. All spices used were from the brand Gardenia ${ }^{\circledR}$. The used brand for mayonnaise, mustard and sunflower oil was Plein Soleil®. The brand used for grenadine molasses and vinegar was Yamama®.

\subsection{Preparation Procedure}

Fresh boneless breast meat of broiler chickens obtained from a local processing plant was used in this study. External fat, skin and connective tissues associated with breast meat were manually removed. The boneless breast meat was cut into $1000 \mathrm{~g}$ pieces. The marinating process consisted of immersion of breast meat in the prepared marinade - mix 1 , mix 2 , and mix 3 - Samples from the groups were immersed in the marinade inside plastic containers. The breast meat was stored in a refrigerator at $4^{\circ} \mathrm{C} \pm 1{ }^{\circ} \mathrm{C}$ in atmospheric conditions. The components of each container were mixed every 1 hour.

\subsection{Sensory Evaluation}

Descriptive testing was used to quantify the perceived intensities of color and flavor of a certain marinated Tawouk using a 5-point anchored just about right (JAR) scale. Hedonic or effective testing was used to quantify the degree of overall liking or disliking of a certain marinated Tawouk. Juiciness and chewiness were tested by using a 9point hedonic scale.
Table 1. Ingredients of the three marinade solutions per $500 \mathrm{~g}$ of breast meat

\begin{tabular}{c|ccc}
\multicolumn{1}{c}{ Ingredients } & Mix 1 & Mix 2 & Mix 3 \\
\hline Salt & $7.5 \mathrm{~g}$ & $7.5 \mathrm{~g}$ & $7.5 \mathrm{~g}$ \\
Vinegar & $15 \mathrm{ml}$ & $15 \mathrm{ml}$ & $15 \mathrm{ml}$ \\
Sunflower Oil & $30 \mathrm{ml}$ & $30 \mathrm{ml}$ & $30 \mathrm{ml}$ \\
Lemon Juice & $8 \mathrm{ml}$ & $8 \mathrm{ml}$ & $8 \mathrm{ml}$ \\
Garlic & $6 \mathrm{~g}$ & $6 \mathrm{~g}$ & $6 \mathrm{~g}$ \\
Yogurt & $15 \mathrm{ml}$ & $15 \mathrm{ml}$ & $15 \mathrm{ml}$ \\
Tawouk Spice & $3.75 \mathrm{ml}$ & $3.75 \mathrm{ml}$ & $3.75 \mathrm{ml}$ \\
Peppercorn & $3.75 \mathrm{~m}$ & $3.75 \mathrm{ml}$ & - \\
White Pepper & - & - & $3.75 \mathrm{ml}$ \\
Paprika & $7.5 \mathrm{ml}$ & - & - \\
Grenadine & $15 \mathrm{ml}$ & - & - \\
Molasses & & & - \\
Mustard & - & $30 \mathrm{ml}$ & - \\
Curry & - & $7.5 \mathrm{ml}$ & - \\
Mayonnaise & - & - & $15 \mathrm{ml}$ \\
& & &
\end{tabular}

Twenty trained panelists were chosen to conduct the sensory evaluation test. The chewiness and overall acceptability were tested by 9-point hedonic scale. Also, panelists trained to use a 5-point anchored just about right (JAR) scale to evaluate flavor (1- too mild, 2-mild, 3- just about right, 4- strong, and 5-too strong) and color (1- Too light, 2-light,3- Just about right, 4-dark, and 5-too dark) attributes.

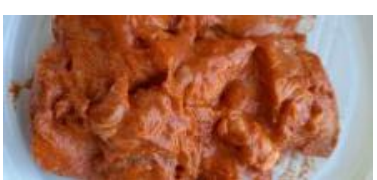

(a)

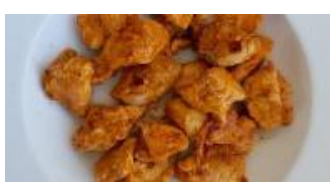

(b)
Fig.1: Pictures of chicken breast samples treated with mix one marinade before cooking (a) and after cooking (b) prepared for sensory evaluation after $6 \mathrm{~h}$ marination

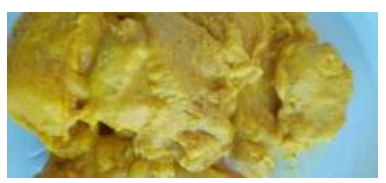

(a)

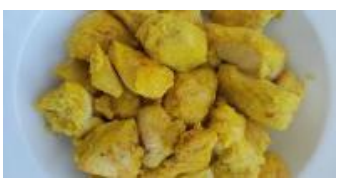

(b)
Fig.2: Pictures of chicken breast samples treated with mix two marinade before cooking (a) and after cooking (b) prepared for sensory evaluation after $6 \mathrm{~h}$ marination. 


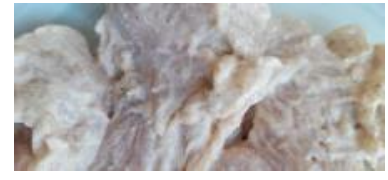

(a)

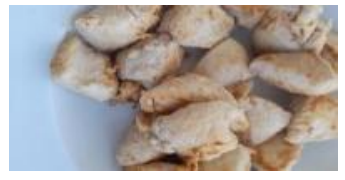

(b)

Fig.1: Pictures of chicken breast samples treated with mix three marinade before cooking ( $a$ ) and after cooking (b) prepared for sensory evaluation after $6 \mathrm{~h}$ marination.

Raw chicken breast samples were placed on labelled cooking sheets, and the samples were then covered with a single aluminum foil layer. Covered samples were placed in the ovens' center rack and cooked in a preheated $180^{\circ} \mathrm{C}$ oven for $15 \mathrm{~min}$. For testing, chicken breast samples were prepared for presentation by cutting into $2 \mathrm{~cm}$ cubes then dispensed into lidded souffle cups with three-digit codes.

All candidates were between the age of 20 and 48 years and lives in the Bekaa area (east of Lebanon). These 20 panelists were 12 females and 8 males. We modified the sensory tests conditions due to Covid-19 circumstances so instead of indoor testing, we used an outdoor set up to ensure social distancing and safety measures. The panelists rinsed their mouth with water and crackers between samples.

\subsection{Data Analysis}

Differences in color, flavor, juiciness and chewiness for each treatment were assessed using one-way ANOVA, Duncan mean separation, cluster analysis and correlation.

\section{RESULTS AND DISCUSSION}

Using one-way ANOVA, we studied the variability between distinct treatments with respect to chicken color, flavor, juiciness, chewiness and overall acceptability (Table 2). Our results showed a highly significant difference in color ( $p$-value $<0.01$ ), flavor ( $p$-value $<0.01$ ), and juiciness $(<0.05)$ between different treatments. In contrast, there was no significant difference among all treatments in term of chewiness and overall acceptability.

Table 2. One-way ANOVA for the difference between

Dependent Variable

\begin{tabular}{|c|c|}
\hline Color & .000 \\
Flavor & .000 \\
\hline Juiciness & .039 \\
Chewiness & .625 \\
\hline Overall Acceptability & .092 \\
\hline
\end{tabular}

Using Duncan mean separation for the treatments concerning color, treatments were grouped into four categories (Table 3). Results showed that the color of chicken breast samples treated with mix one for 12 hours were the most preferred color among the panelists. Chicken breast samples treated with mix one for 6 hours and mix three for 12 hours were not significantly different in color, but they were distinct from other treatments. The least preferred treatments concerning color were the chicken breast samples treated with mix three for 3 hours and mix two for 3 hours ( $p$-value > 0.05).

To study the effect of different treatments on flavor (Table 1), treatments were grouped into four categories, and results showed that chicken breast samples treated with mix one for 12 hours and mix one for 6 hours were the most preferred in terms of flavor (p-value <0.05), and were significantly different from other treatments. Chicken breast samples treated with mix three for 12 hours, mix two for 12 hours, mix three for 6 hours and mix two for 6 hours were not significantly different from each other, but they were significantly different from other treatments. Chicken breast samples treated with mix three for 3 hours were not significantly different and had the least preferable flavor for the panelists (Table 3).

In terms of juiciness, treatments were grouped into three categories. Results showed that chicken breast samples treated with mix two for 6 hours were the most significant and thus preferred treatment (6.3). Chicken breast samples treated with mix two for 6 hours were significantly different in their juiciness from those treated with mix one for 3 hours (5.4), mix one for 6 hours and mix one for 12 hours. Chicken breast samples treated with mix three for 6 hours were significantly different in their juiciness from those treated with mix one for 3 hours (Table 3 ).

Table 3. Estimated marginal means of statistically significant $(\alpha=0.05)$ sensory attributes $(n=20)$

\begin{tabular}{c|ccc} 
Treatment & Color & Flavor & Juiciness \\
\hline Mix3-3hrs & $1.5^{\mathrm{d}}$ & $1.85^{\mathrm{d}}$ & $5.9^{\mathrm{a}, \mathrm{b}, \mathrm{c}}$ \\
Mix2-3hrs & $1.55^{\mathrm{d}}$ & $2.3^{\mathrm{c}, \mathrm{d}}$ & $5.9^{\mathrm{a}, \mathrm{b}, \mathrm{c}}$ \\
Mix1-3hr & $1.8^{\mathrm{c}, \mathrm{d}}$ & $2.35^{\mathrm{c}, \mathrm{d}}$ & $5.4^{\mathrm{c}}$ \\
Mix2-6hrs & $1.8^{\mathrm{c}, \mathrm{d}}$ & $3.15^{\mathrm{b}}$ & $6.3^{\mathrm{a}}$ \\
Mix3-6hrs & $2.05^{\mathrm{c}}$ & $2.8^{\mathrm{b}, \mathrm{c}}$ & $6.05^{\mathrm{a}, \mathrm{b}}$ \\
Mix2-12hrs & $2.1^{\mathrm{c}}$ & $3.8^{\mathrm{a}}$ & $5.95^{\mathrm{a}, \mathrm{b}, \mathrm{c}}$ \\
Mix3-12hrs & $2.65^{\mathrm{b}}$ & $2.9^{\mathrm{b}}$ & $5.9^{\mathrm{a}, \mathrm{b}, \mathrm{c}}$ \\
Mix1-6hrs & $2.95^{\mathrm{b}}$ & $3.15^{\mathrm{b}}$ & $5.65^{\mathrm{b}, \mathrm{c}}$ \\
Mix1-12hrs & $3.9^{\mathrm{a}}$ & $3.9^{\mathrm{a}}$ & $5.7^{\mathrm{b}, \mathrm{c}}$ \\
\multicolumn{2}{c}{ a,b,c,d Values within an sensory attribute with differing } \\
\multicolumn{2}{c}{ superscript letters are significantly different $(\alpha=0.05)$}
\end{tabular}


Table 4. Pearson correlation between the sensory attributes based on their means
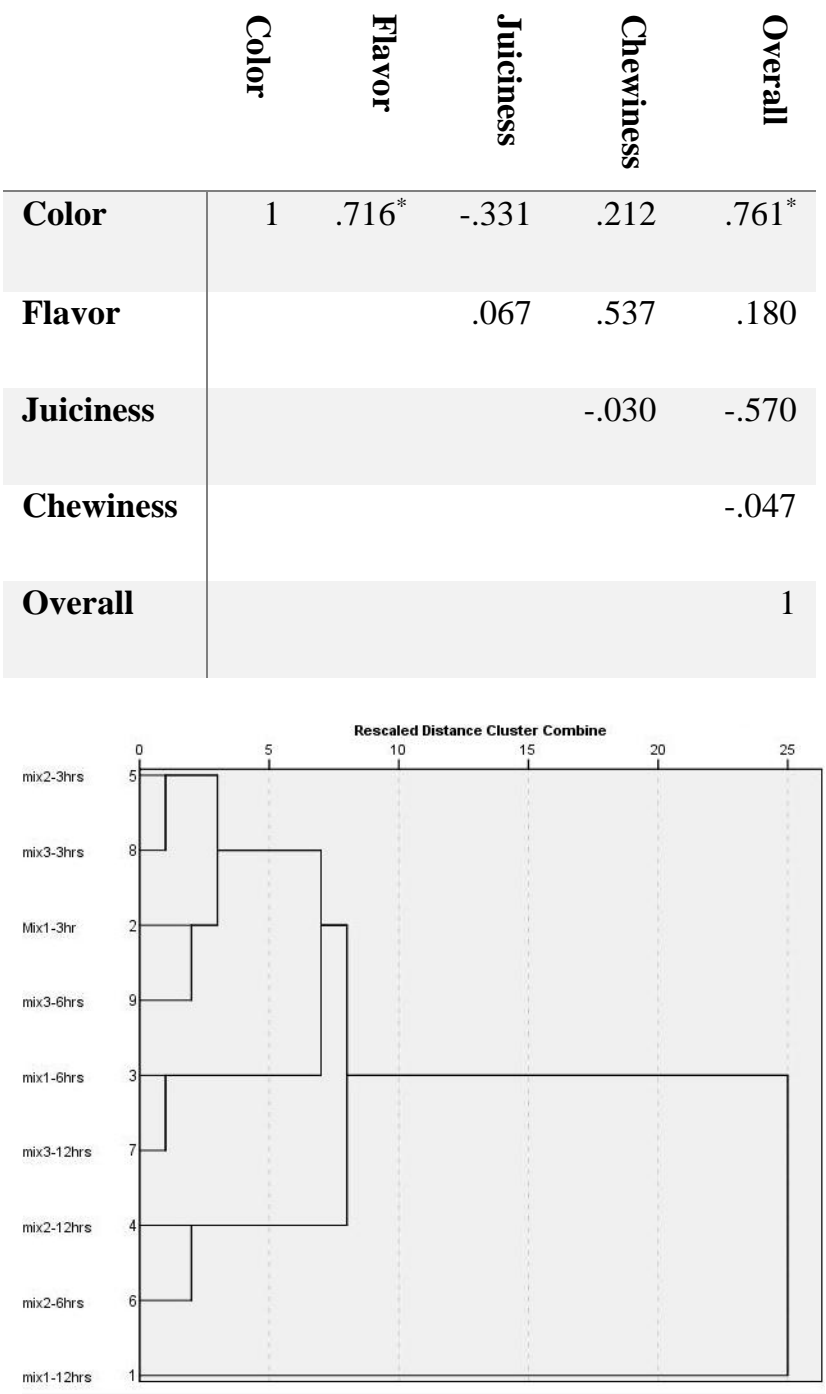

Fig.4: Dendrogram Using Average Linkage based on color, flavor, juiciness, chewiness and overall acceptability of treatments.

Next, we investigated the correlation between the five studied variables based on their means (Table 4). Our results showed a significant correlation between color and flavor, and between color and overall acceptability.

Cluster analysis based on color, flavor, juiciness, chewiness and overall acceptability, demonstrated that all treatments were similar, except chicken breast samples treated with mix one for 12 hours, which were highly favored by the panelists (Fig. 4).

\section{CONCLUSION}

We studied the effect of various combinations of marination ingredients and duration on flavor, color, juiciness, chewiness, and overall acceptability of Tawouk.
Our work showed a significant difference in consumer preference based on color and flavor between different treatments and a significant difference in juiciness between other treatments. Chicken breast samples treated with mix one for 12 hours were significantly preferred over all other treatments in terms of flavor and color; however, they were equally favored as samples treated with mix one for 6 hours in terms of color alone. Chicken breast sample treated with mix two for 6 hours was the most preferred treatment concerning juiciness. Our results showed a significant correlation between color and flavor and a significant correlation between color and overall acceptability.

\section{REFERENCES}

[1] Ministry of Agriculture/Food and Agriculture Agricultural Census Project. (2003). Analysis and Assessment of the Poultry Sector in Lebanon. Ali H. Retrieved October 19, 2020. http://agriculture.gov.lb/Statistics-andStudies/Studies-and-Publications

[2] Ruiz, D., Borrell, D., Xargayó, M., Lagares, J., \& Fernandez, E. (2001). Marination of fresh meats by means of spray effect. Fleischwirtschaft international: journal for meat production and meat processing, 70-74.

[3] He, F.Y., Kim, H.W., Hwang, K.E., Song, D.H., Kim, Y.J., Ham, Y.K., Kim, S.Y., Yeo, I.J., Jung, T.J., and Kim, C.J. (2015). Effect of ginger extract and citric acid on the tenderness of duck breast muscles. Korean J Food Sci An 35,721-730. DOI: 10.5851/kosfa.2015.35.6.721

[4] United States Department of Agriculture Food Safety and Inspection Service. (2007). Barbecue and Food Safety Retrieved December 10, 2020. http://blogs.ifas.ufl.edu/levyco/files/2017/08/Barbecue_Foo d_Safety.pdf

[5] Gutierrez J., Barry-Ryan C., Bourke P. (2008). The antimicrobial efficacy of plant essential oil combinations and interactions with food ingredients, Int. J. Food Microbiol, 124, 91-97.

[6] Istrati, D., Constantin, O., Ionescu, A., Vizireanu, C. and Dinica, R. (2011). Study of the combined effect of spices and marination on beef meat vacuum packaged. Ann. Univ. Dunarea Galati Fascicle VI - Food Technol. 35, 75-85.

[7] Alvarado, C., \& Mckee, S. (2007). Marination to Improve Functional Properties and Safety of Poultry Meat. The Journal of Applied Poultry Research, 16, 113-120.

[8] Gill, J., Yogavel, M., Kumar, A., Belrhali, H., Jain, S.K., Rug, M., Brown, M., Maier, A.G., Sharma, A. (2009). Crystal structure of malaria parasite nucleosome assembly protein distinct modes of protein localization and histone recognition. Journal of Biological Chemistry, 284. pp. 10076-10087. ISSN 0021-9258

[9] Graiver, N., Pinotti, A., Califano, A., \& Zaritzky, N. (2006). Diffusion of sodium chloride in pork tissue. Journal of Food Engineering, 77, 910-918. DOI:10.1016/j.jfoodeng.2005.08.018 
[10] Knight, P., Parsons, N. (1988). Action of $\mathrm{NaCl}$ and Polyphosphates in Meat Processing: Responses of Myofibriis to Concentrated Salt Solutions. Meat Science. 24,275-300. https://doi.org/10.1016/03091740(88)90040-X

[11] Offer, G., \& Trinick, J. (1983). On the mechanism of water holding in meat: The swelling and shrinking of myofibrils. Meat science. 8(4), 245-281. https://doi.org/10.1016/03091740(83)90013-X

[12] Safe and Suitable Ingredients Used in the Production of Meat and Poultry Products. USDA-FSIS. Directive7120-1Amendment 6, 2006. 